\title{
Neutralization-enhancing RF antibodies for HIV vaccines
}

\author{
Konstantin V. Suslov* \\ Institute of Immunology, Moscow, Russia \\ *Correspondence: suslov_kv@mail.ru \\ Edited by: \\ Annapurna Vyakarnam, King's College London, UK \\ Reviewed by: \\ Ann Jones Hessell, Oregon Health \& Science University, USA
}

Keywords: HIV, gp120 glycoprotein, neutralizing antibodies, rheumatoid factor, neutralization-enhancing RF antibodies, repeated immunization, microspheres, HIV vaccine

Efficient neutralization of HIV is a primary goal both for therapeutic and prophylactic HIV vaccines based on induction of neutralizing antibodies (NAbs) $(1,2)$. Neutralization capacity of NAbs correlates with their affinity to HIV-1 gp120 envelope glycoprotein (3). In HIV-infected individuals, early IgM antibodies have low affinity for gp120 glycoprotein (3), which is slightly compensated by their pentameric structure and avidity to multivalent structures of the virus. Corresponding IgG1 antibodies (3, 4), which appear later from IgM through the CSR and SHM processes $(3,5)$, have high affinity and specificity to gp120, but low avidity due to monomeric structure of IgG. The question is how to induce HIVspecific NAbs with both high affinity and avidity to gp120?

Anti-HIV IgG antibodies 2F5 and 2G12, switched back to IgM isotype, showed increased avidity and neutralization efficacy (2). Dendritic antibody supramolecules (DAS) in one molecule combine high specificity of IgG with high avidity of IgM (6). It would be of interest to construct such a DAS with IgM as a core, carrying 10 anti-gp120 IgG monomers. Natural monomeric anti-gp120 IgG1 antibodies (3, 4) not only have low avidity insufficient for effective neutralization of HIV but may also contribute to FcR-mediated infection enhancement $(7,8)$. Does it mean that HIV may use high-affinity IgG antibodies for its own purposes? Fortunately, in nature there exist some helpful network-like regulatory mechanisms with a key role of RF antibodies (9).

Rheumatoid factor (RF) is an autoantibody which specifically binds $F c$ region of $\operatorname{IgG}(10,11)$. Apart from pathologic RF in rheumatoid arthritis (12), natural RF appears in many non-rheumatoid states (13). Possible beneficial physiological roles of RF include enhanced clearance of immune complexes (ICs) (14), amplification of IgG response to pathogens (15), and enhancement of virus neutralization $(16,17)$. RF can be induced in vivo in a highly specific way either by secondary immunization with protein antigens or in response to immunization with the newly formed ICs $(10,11)$. New antigenic determinants, which appear in the $\mathrm{Fc}$ region of IgG antibody upon antibody-antigen complex formation, may strengthen the specificity of RF (9).

The level of RF was significantly higher in some of HIV-infected individuals compared to control groups (18-22). RFs were mainly IgA, IgM immunoglobulins with specificity against anti-HIV IgG (20). RF-mediated enhancement of antiHIV IgG neutralization activity was found in the sera from MCTD patients (17). Authors suggested that RF is promising for passive immunotherapy based on NAbs (17).

Can RF play a key role in specific enhancement of IgG-mediated neutralization of HIV in vivo? Measurements of RF level both in long-term non-progressors (23) and dual-infected individuals (24) might give some clues. Repeated immunization of uninfected macaques with HIV1 gp120 glycoprotein may allow researchers not only to track the kinetics of RF induction but also to elucidate whether neutralization-enhancing RF antibodies can protect macaques against subsequent challenge with SHIV. Repeated immunization of SHIV-infected macaques with HIV1 gp120 glycoprotein might show whether neutralization-enhancing RF antibodies can prolong the asymptomatic period and delay the onset of AIDS.
The level of RF is not stable and has a tendency to decline during the acute phase of HIV infection (22). Prolonged repeated immunizations with gp120 (e.g., immunizations every 3 weeks; the actual time between immunizations will be adjusted according to measurements of RF level in patients) would be the solution to keep the level of neutralization-enhancing RF antibodies constantly high. Singleadministration vaccine (SAV) technology, which is based on pulsatile release of gp120 from biodegradable polymeric microspheres, mimics repeated immunization scheme, and allows vaccination to be done in one shot $(25,26)$.

Patient-specific therapeutic HIV vaccines (1) even in simplified version, using the only one gp120 variant formed after completion of HIV population homogenization process (27), can be performed via repeated immunizations from biodegradable polymeric microspheres under SAV $(25,26)$ technology platform. Prophylactic HIV vaccines can be based on the variations of sequential scheme (28) for prolonged pulsatile release of gp120 glycoproteins from biodegradable polymeric microspheres in single-shot $(25,26)$ way convenient for both patients and doctors.

Studies $(15,17)$ have shown the high potential of neutralization-enhancing RF antibodies, but several principal questions arise:

(i) Can neutralization-enhancing RF antibodies (NeRFa) be induced after repeated immunization of humans with recombinant gp120 glycoprotein?

(ii) Will the power of gp120 immunogen design (29-31) combined with an optimal vaccination regimen help the induction of $\mathrm{NeRFa}$ ? 
(iii) Could NeRFa help to improve the efficacy of previous (32) and future HIV vaccines based on induction of NAbs?

(iv) Might induction of NeRFa be a future promising method not only against malaria as suggested in Ref. (33), but also against life-threatening viruses like Ebola (34)?

Repeated immunization with gp120 glycoprotein might lead to prolonged induction of neutralization-enhancing RF antibodies with a potential to be explored for finding the ways to extend lives of HIVinfected individuals and to stop current HIV pandemic.

\section{REFERENCES}

1. Suslov KV. AID-mediated somatic hypermutation for generation of viral envelope protein diversity in patient-specific therapeutic HIV vaccines based on induction of neutralizing antibodies. Immunol Lett (2010) 128:86-7. doi:10.1016/j.imlet.2009.11.004

2. Wolbank S, Kunert R, Stiegler G, Katinger H. Characterization of human class-switched polymeric (immunoglobulin $\mathrm{M}[\mathrm{IgM}]$ and $\operatorname{IgA}$ ) antihuman immunodeficiency virus type 1 antibodies 2F5 and 2G12. J Virol (2003) 77:4095-103. doi:10.1128/JVI.77.7.4095-4103.2003

3. Torán JL, Kremer L, Sánchez-Pulido L, de Alborán IM, del Real G, Llorente M, et al. Molecular analysis of HIV-1 gp120 antibody response using isotype $\operatorname{IgM}$ and IgG phage display libraries from a long-term non-progressor HIV-1-infected individual. Eur J Immunol (1999) 29:2666-75. doi:10.1002/(SICI)1521-4141(199909)29: 09<2666::AID-IMMU2666>3.0.CO;2-Q

4. Khalife J, Guy B, Capron M, Kieny MP, Ameisen JC, Montagnier L, et al. Isotypic restriction of the antibody response to human immunodeficiency virus. AIDS Res Hum Retroviruses (1988) 4:3-9. doi:10.1089/aid.1988.4.3

5. Margolin DH, Saunders EH, Bronfin B, de Rosa N, Axthelm MK, Goloubeva OG, et al. Germinal center function in the spleen during simian HIV infection in rhesus monkeys. I Immunol (2006) 177:1108-19. doi:10.4049/jimmunol.177.2.1108

6. Harada A, Yamaguchi H, Tsubouchi K, Horita E. Dendritic antibody supramolecules: combination of IgM and IgG. Chem Lett (2003) 32:18-9. doi:10.1246/cl.2003.18

7. Takeda A, Tuazon CU, Ennis FA. Antibodyenhanced infection by HIV-1 via Fc receptormediated entry. Science (1988) 242:580-3. doi:10. 1126/science. 2972065

8. Homsy J, Meyer M, Levy JA. Serum enhancement of human immunodeficiency virus (HIV) infection correlates with disease in HIV-infected individuals. J Virol (1990) 64:1437-40.

9. Nemazee DA, Sato VL. Enhancing antibody: a novel component of the immune response. Proc Natl Acad Sci U S A (1982) 79:3828-32. doi:10. 1073/pnas.79.12.3828
10. Nemazee DA, Sato VL. Induction of rheumatoid antibodies in the mouse. Regulated production of autoantibody in the secondary humoral response. Exp Med (1983) 158:529-45. doi:10.1084/jem.158. 2.529

11. Nemazee DA. Immune complexes can trigger specific, T cell-dependent, autoanti-IgG antibody production in mice. J Exp Med (1985) 161:242-56. doi:10.1084/jem.161.1.242

12. Stewart JJ, Agosto H, Litwin S, Welsh JD, Shlomchik M, Weigert M, et al. A solution to the rheumatoid factor paradox: pathologic rheumatoid factors can be tolerized by competition with natural rheumatoid factors. J Immunol (1997) 159 1728-38.

13. Bartfeld H. Distribution of rheumatoid factor activity in nonrheumatoid states. Ann NY Acad Sci (1969) 168:30-40. doi:10.1111/j.1749-6632.1969. tb43092.x

14. Van Snick JL, Van Roost E, Markowetz B, Cambiaso CL, Masson PL. Enhancement by IgM rheumatoid factor of in vitro ingestion by macrophages and in vivo clearance of aggregated IgG or antigenantibody complexes. Eur J Immunol (1978) 8:279-85. doi:10.1002/eji.1830080412

15. Clarkson AB Jr, Mellow GH. Rheumatoid factorlike immunoglobulin $\mathrm{M}$ protects previously uninfected rat pups and dams from Trypanosoma lewisi. Science (1981) 214:186-8. doi:10.1126/science. 7025211

16. Ashe WK, Daniels CA, Scott GS, Notkins AL. Interaction of rheumatoid factor with infectious herpes simplex virus-antibody complexes. Science (1971) 172:176-7. doi:10.1126/science.172.3979.176

17. Douvas A, Takehana Y, Ehresmann G, Chernyovskiy T, Daar ES. Neutralization of HIV type 1 infectivity by serum antibodies from a subset of autoimmune patients with mixed connective tissue disease. AIDS Res Hum Retroviruses (1996) 12:1509-17. doi:10.1089/aid.1996.12.1509

18. Jackson S, Tarkowski A, Collins JE, Dawson LM, Schrohenloher RE, Kotler DP, et al. Occurrence of polymeric IgAl rheumatoid factor in the acquired immune deficiency syndrome. J Clin Immunol (1988) 8:390-6. doi:10.1007/BF00917155

19. Procaccia S, Lazzarin A, Colucci A, Gasparini A, Forcellini P, Lanzanova D, et al. IgM, IgG and IgA rheumatoid factors and circulating immune complexes in patients with AIDS and AIDS-related complex with serological abnormalities. Clin Exp Immunol (1987) 67:236-44.

20. Jendis JB, Tomasik Z, Hunziker U, Nadal D, Seger R, Wetzel JC, et al. Evaluation of diagnostic tests for HIV infection in infants born to HIV-infected mothers in Switzerland. AIDS (1988) 2:273-9. doi:10.1097/00002030-198808000-00006

21. Jarvis JN, Taylor H, Iobidze M, Dejonge J, Chang S, Cohen F. Rheumatoid factor expression and complement activation in children congenitally infected with human immunodeficiency virus. Clin Immunol Immunopathol (1993) 67:50-4. doi: 10.1006/clin.1993.1044

22. Tomaras GD, Yates NL, Liu P, Qin L, Fouda GG, Chavez LL, et al. Initial B-cell responses to transmitted human immunodeficiency virus type 1: virion-binding immunoglobulin $\mathrm{M}(\operatorname{IgM})$ and IgG antibodies followed by plasma anti-gp41 antibodies with ineffective control of initial viremia. J Virol (2008) 82:12449-63. doi:10.1128/ JVI.01708-08

23. Scarlatti G, Leitner T, Hodara V, Jansson M, Karlsson A, Wahlberg J, et al. Interplay of HIV-1 phenotype and neutralizing antibody response in pathogenesis of AIDS. Immunol Lett (1996) 51:23-8. doi:10.1016/0165-2478(96)02550-3

24. Esbjörnsso J, Månsson F, Kvist A, Isberg PE, Biague AJ, da Silva ZJ, et al. Increased survival among HIV-1 and HIV-2 dual-infected individuals compared to HIV-1 single-infected individuals. AIDS (2014) 28:949-57. doi:10.1097/QAD. 0000000000000101

25. Cleland JL. Single-administration vaccines: controlled-release technology to mimic repeated immunizations. Trends Biotechnol (1999) 17:25-9. doi:10.1016/S0167-7799(98)01272-4

26. Cleland JL, Lim A, Daugherty A, Barron L, Desjardin N, Duenas ET, et al. Development of a single-shot subunit vaccine for HIV-1. 5. programmable in vivo autoboost and long lasting neutralizing response. J Pharm Sci (1998) 87:1489-95. doi:10.1021/js980263f

27. Learn GH, Muthui D, Brodie SJ, Zhu T, Diem K, Mullins JI, et al. Virus population homogenization following acute human immunodeficiency virus type 1 infection. J Virol (2002) 76:11953-9. doi:10.1128/JVI.76.23.11953-11959.2002

28. Klinman DM, Higgins KW, Conover J. Sequential immunizations with rgp120s from independent isolates of human immunodeficiency virus type 1 induce the preferential expansion of broadly crossreactive B cells. J Exp Med (1991) 173:881-7. doi:10.1084/jem.173.4.881

29. Kwong PD, Mascola JR. Human antibodies that neutralize HIV-1: identification, structures, and B cell ontogenies. Immunity (2012) 37:412-25. doi:10.1016/j.immuni.2012.08.012

30. McElrath MJ, Haynes BF. Induction of immunity to human immunodeficiency virus type- 1 by vaccination. Immunity (2010) 33:542-54. doi:10.1016/ j.immuni.2010.09.011

31. Bonsignori M, Alam SM, Liao HX, Verkoczy L, Tomaras GD, Haynes BF, et al. HIV-1 antibodies from infection and vaccination: insights for guiding vaccine design. Trends Microbiol (2012) 20:532-9. doi:10.1016/j.tim.2012.08.011

32. Montefiori DC, Karnasuta C, Huang Y, Ahmed H, Gilbert P, de Souza MS, et al. Magnitude and breadth of the neutralizing antibody response in the RV144 and Vax003 HIV-1 vaccine efficacy trials. J Infect Dis (2012) 206:431-41. doi:10.1093/ infdis/jis367

33. Green TJ, Packer BJ. A role for rheumatoid factor enhancement of Plasmodium falciparum schizont inhibition in vitro. Infect Immun (1984) 46: 668-72.

34. Wong G, Audet J, Fernando L, Fausther-Bovendo $\mathrm{H}$, Alimonti JB, Kobinger GP, et al. Immunization with vesicular stomatitis virus vaccine expressing the Ebola glycoprotein provides sustained long-term protection in rodents. Vaccine (2014) 32:5722-9. doi:10.1016/j.vaccine.2014.08. 028 
Conflict of Interest Statement: The author declares that the research was conducted in the absence of any commercial or financial relationships that could be construed as a potential conflict of interest.

Received: 22 August 2014; accepted: 26 November 2014; published online: 16 December 2014.
Citation: Suslov KV (2014) Neutralization-enhancing RF antibodies for HIV vaccines. Front. Immunol. 5:634. doi: 10.3389/fimmu.2014.00634

This article was submitted to HIV and AIDS, a section of the journal Frontiers in Immunology.

Copyright (c) 2014 Suslov. This is an open-access article distributed under the terms of the Creative Commons
Attribution License (CC BY). The use, distribution or reproduction in other forums is permitted, provided the original author(s) or licensor are credited and that the original publication in this journal is cited, in accordance with accepted academic practice. No use, distribution or reproduction is permitted which does not comply with these terms. 